\title{
Recent changes in the Norske Øer Ice Barrier, coastal Northeast Greenland
}

\author{
William A. SNEED, ${ }^{1}$ Gordon S. HAMILTON ${ }^{1,2}$ \\ ${ }^{1}$ Climate Change Institute, University of Maine, Orono, ME, USA \\ E-mail: william.sneedjr@maine.edu \\ ${ }^{2}$ School of Earth and Climate Sciences, University of Maine, Bryand Global Sciences Building, Orono, ME, USA
}

\begin{abstract}
In Northeast Greenland, the Norske Øer Ice Barrier (NØIB) abuts Nioghalvfjerdsfjorden $(79 N)$ and Zachariae Isstrøm (ZI), two floating outlets of the Northeast Greenland Ice Stream. NØIB is an extensive region of perennially fast sea ice, which varies in size from year to year, but with complete breakup a rare event in the 20th century. It reportedly broke up in the 1950s and was seen to break up in 1997. Since 2000 the NØIB has broken up during 11 of the last 14 summers. The forcings driving the increased frequency of ice barrier breakup are poorly understood, and it is not clear if the breakup is a purely local phenomenon or an indicator of regional changes in the ocean and atmosphere. Here we use a logistic regression statistical model to show that the odds of breakup are linked to June positive degree days and July wind speeds at a nearby weather station. It is too soon to know if subtle changes detected on $79 \mathrm{~N}$ and $\mathrm{ZI}$ in the last decade are connected to breakups of the NØIB but, if they are, it suggests a complex interaction between the atmosphere, ocean and outlet glaciers in this part of Greenland.
\end{abstract}

KEYWORDS: atmosphere/ice/ocean interactions, sea-ice/ice-shelf interactions

\section{INTRODUCTION}

Sea ice can potentially exert an important control on the behavior of Greenland's outlet glaciers (Reeh and others, 2001). For example, it can mechanically retard iceberg calving at the terminus (e.g. Amundson and Truffer, 2010). Or it can modulate the delivery of oceanic heat to the terminus, and hence submarine melting, because it acts as a rigid cap between the atmosphere and near-terminus ocean waters, which damps the circulation (e.g. Straneo and others, 2013). In Northeast Greenland, the Norske Øer Ice Barrier (NØIB) (Fig. 1) abuts Nioghalvfjerdsfjorden (79N) and Zachariae Isstrøm (ZI), two floating outlets of the Northeast Greenland Ice Stream (NEGIS). Loss of these floating sections might trigger inland migration of the grounding lines, given NEGIS's configuration in a bedrock trough below sea level (Bamber and others, 2013).

The NØIB is an extensive region of perennially fast ice, which varies in size from year to year (Fig. 2) with complete breakups hitherto a rare event. It has been variously described as landfast ice (de Gerlache, 1906; Wadhams, 1981), a shelf ice barrier (Schneider and Budéus, 1994), shorefast ice (Gudmandsen and others, 1995) and fast ice (Budéus and Schneider, 1995); here we will use the term fast ice as defined by the World Meteorological Organization (World Meteorological Organization, 2014, p. 6). Fast ice is:

"Sea ice which forms and remains fast along the coast, where it is attached to the shore, to an ice wall, to an ice front, between shoals or grounded icebergs. Vertical fluctuations may be observed during changes of sealevel. Fast ice may be formed in situ from sea water or by freezing of floating ice of any age to the shore, and it may extend a few metres or several hundred kilometres from the coast. Fast ice may be more than 1 a old and may then be prefixed with the appropriate age category (old, second-year, or multi-year). If it is thicker than about $2 \mathrm{~m}$ a.s.l. it is called an ice shelf."
It reportedly broke up in the 1950s (Wadhams, 1981) and was seen to breakup in August, 1997 (Reeh and others, 2001). However, since the start of the century, the NØIB has broken up during the summers of 2001-2005, 2008, and 2010-2014. What do we mean by a breakup? In some years (e.g. 2001), only the portion of fast ice in front of $79 \mathrm{~N}$ breaks and is dispersed. In other years (e.g. 2008), all of the fast ice, including that west of Norske Øer (islands), Franske $\varnothing$ (island) and île de France, breaks into multiple floes although the floes do not disperse before first-year ice begins to form. In 2002, all the fast ice from the Henrik Krøyer Holme islands (HKH in Fig. 1b) to Danmarkshavn broke up and was completely dispersed before first-year ice began to form. The years when fast ice is not abutting the termini of either $79 \mathrm{~N}$ or $\mathrm{ZI}$ are the years when these large glaciers are most likely to calve (e.g. 2002 for $79 \mathrm{~N}$ and 2014 for $\mathrm{ZI}$ ).

While each of the yearly breakups between 2001 and 2013 is somewhat unique, there is a general spatial and temporal pattern to them all. The average date when the ice barrier is completely shattered and the floes are dispersing is 25 August (day 237); 31 July 2003 (day 212) is the earliest and 19 September 2001 (day 262) is the latest date. Note that these days are approximate and all these dates should be taken with some caution depending on the availability of cloud-free images (typically 5-20 images per summer). The ice barrier generally begins to break up in the area northeast of the Île de France (Fig. 1b) at the northwestern end of Belgica Trough (Fig. 5b) by late June-early July. During the same period melt ponds form on the ice barrier and leads begin to open. The edge of the ice barrier continues to deteriorate in a northerly direction toward the Norske Øer. In some years (2002, 2008, 2011 and 2013) very large floes ( 32 $\mathrm{km} \times \sim 26 \mathrm{~km}$ ) break off in the area east of the $79 \mathrm{~N}$ terminus during late July and early August.

The presence of Tobias Island or Tuppiap Qeqertaa $\sim 80$ $\mathrm{km}$ east of the $79 \mathrm{~N}$ terminus (Fig. 1b) may play a role in 

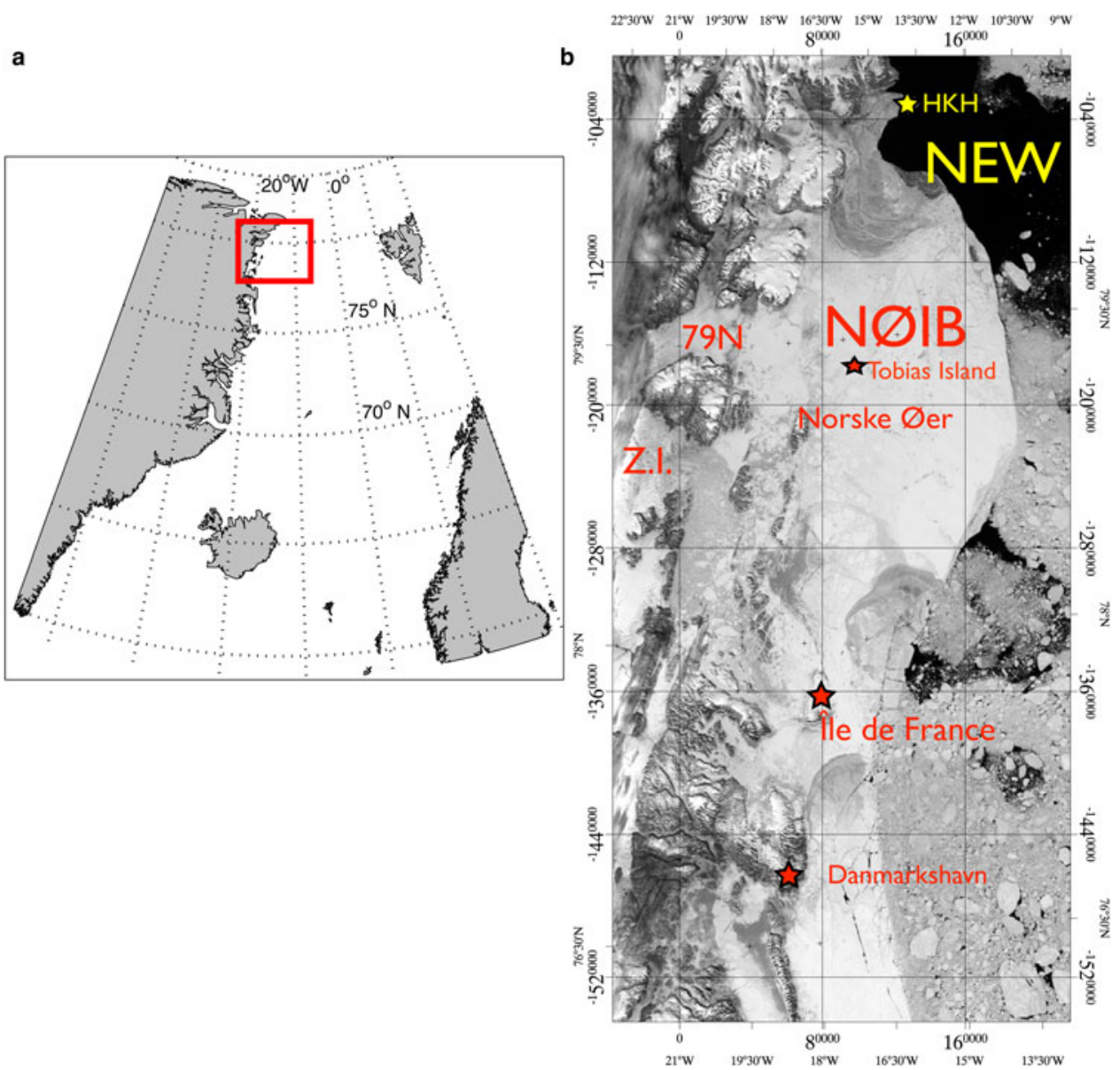

Fig. 1. (A) Location of the study area. (B) MODIS satellite image of 16 June 2012 . The ice barrier extended $\sim 140 \mathrm{~km}$ east of $79 \mathrm{~N}$ and $\sim 375 \mathrm{~km}$ from south to north. The NEW is in the upper right of the image. By 31 July the entire ice barrier was shattered and beginning to disperse and on 15 August all that remained were a few large tabular floes. HKH is the Danish weather station on one of the HKH islands. The image is projected as Polar Stereographic and the rectangular grid is meters south and east of the reference latitude, $90^{\circ} \mathrm{N}$, and reference longitude, $21^{\circ} \mathrm{W}$.

formation (regrowth) of the NØIB. It is $\sim 2 \mathrm{~km}$ long and 1.5 $\mathrm{km}$ wide and rises $\sim 35 \mathrm{~m}$ a.s.l. (Bennike and others, 2006). However, the patterns of the breakup of the ice barrier show no spatial association to the island.

An important feature of Northeast Greenland coastal marine environment is the Northeast Water (NEW) polynya. In the summer of 1933, Lauge Koch made a number of flights over northeast Greenland from a ship anchored off Norske Øer and noted a $100 \mathrm{~km}$ stretch of open water between Nordöstrundingen, Greenland's most northeasterly cape and $79 \mathrm{~N}$. He suggested that the open water existed because it was sheltered from the sea ice exiting through the Fram Strait and flowing southward (Koch, 1935). This hypothesis was supported and refined almost 60 years later by Schneider and Budéus (1994) based on data collected during a 1991 cruise and a follow-up study in the spring and summer of 1993. They proposed that two ice barriers, one along the Ob Bank southeast of Nordöstrundingen and another centered on Norske Øer, the NØIB, were major factors in the creation and the persistence of the NEW polynya. The ice barrier at the Ob Bank, acts to push the southward flowing sea ice within the East Greenland Current to the east away from the coast, while the NØIB blocks sea ice entrained in the Northeast Greenland Coastal Current (Fig. 5b) from flowing northward into the polynya (Schneider and Budéus, 1995, Fig. 2).
In this paper we investigate regional ocean and atmospheric changes that have led to the almost annual breakup of the NØIB since 2001. We present a statistical model that is both an explanatory model of past breakups and a predictive model of future breakups. Later, we consider the possible contributions of changing ice thickness, surface meltwater and the warming of the waters flowing beneath the ice barrier to break up.

\section{A LOGISTIC REGRESSION MODEL}

We undertook a statistical analysis of climate and environmental factors to account for the recent, almost-annual breakup of the NØIB. In the problem at hand, the response or dependent variable (DV), whether the NØIB is either intact or not intact, is binary or dichotomous. (One may arbitrarily assign the numerical value, 1 , to intact or not intact.) The independent or explanatory variables (IVs) that are the predictors of the probability of the DV may be dichotomous (or more complex, e.g. yes/no/maybe) or discrete or continuous numerical values or any combination of the three. Here, all the IVs are discrete or continuous numerical values,

$$
E\left(Y_{i} \mid X_{i}\right)=\pi_{i}=\alpha+\beta_{1} X_{1}+\beta_{2} X_{2}+\cdots+\beta_{n} X_{n},
$$

where $\alpha$ is the intercept, $\beta$ the regression coefficients, $Y_{i}$ is the DV and $X_{i}$ the IVs. 


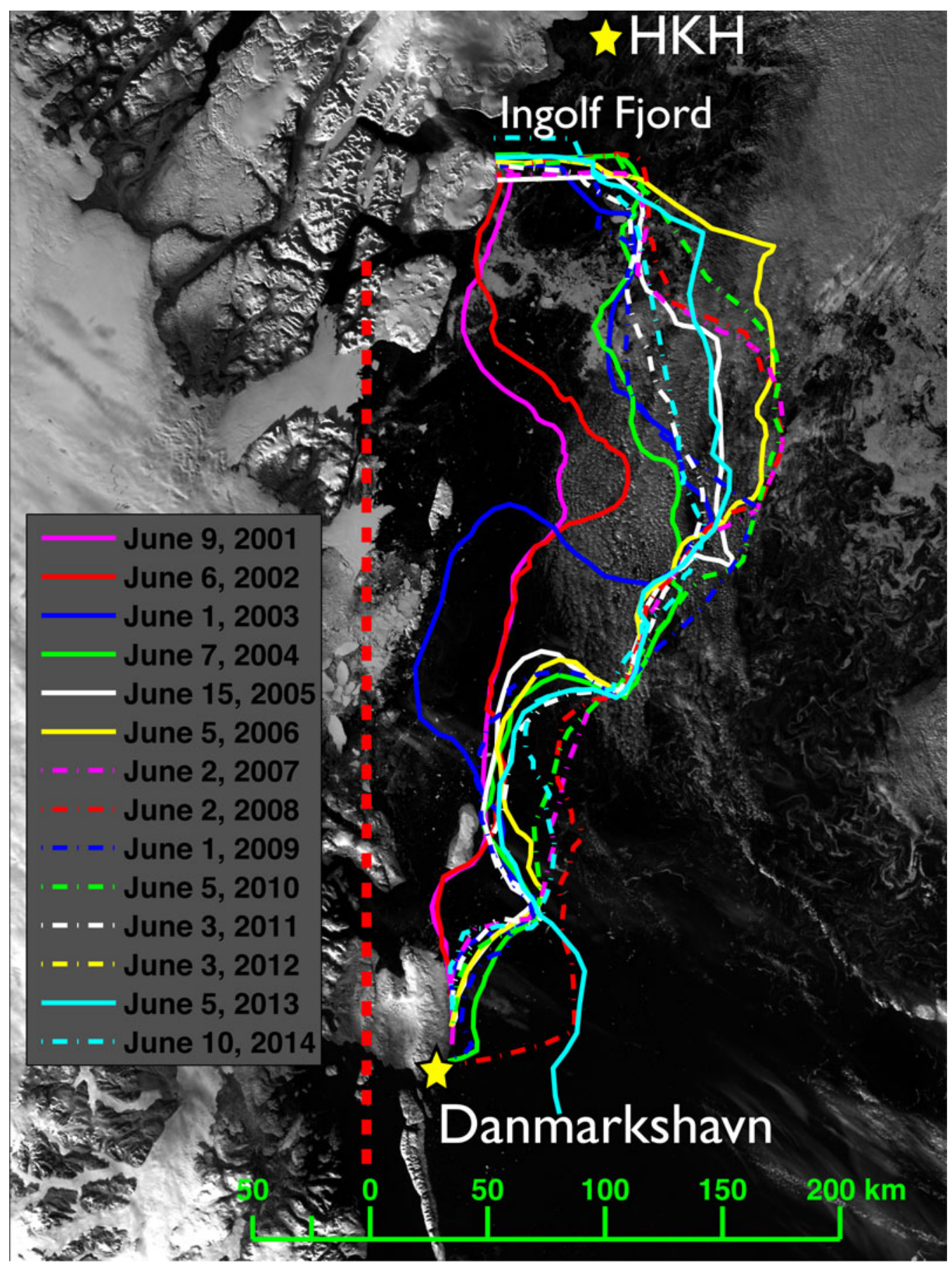

Fig. 2. Annual maximum extent of the NØIB based on MODIS images. Following Schneider and Budéus (1995, Fig. 10), we map the northern extent of the ice barrier to the entrance of Ingolf Fjord. Only rarely (2013) does the ice barrier extend south of Danmarkshavn. The red, dashed vertical line marks the approximate terminus of $79 \mathrm{~N}$ and serves as a reference line to measure the width of the ice barrier.

However, a simple linear regression is not appropriate when modeling a dichotomous response variable for a number of reasons including the fact that the relationship of the DV to the IVs is not linear and leads to the impossible probabilities, $>1$ or $<0$ (Hosmer and Lemeshow, 2013). In contrast, the logistic function has a sigmoid response that is bounded by 0 and 1 with the general form, $e^{x} / 1-e^{x}$. The logistic model of the probability is,

$$
\hat{\pi}_{i}=\frac{\mathrm{e}^{\beta_{0}+\beta_{i} X_{i}}}{1-\mathrm{e}^{\beta_{0}+\beta_{i} X_{i}}} .
$$

Rather than modeling the probability of an outcome with a change in the IVs, we model the changing odds of an outcome,

$$
\text { Odds }=\frac{\text { Probability of one outcome }}{\text { Probability of the other outcome }}=\frac{\hat{\pi}_{i}}{1-\hat{\pi}_{i}} .
$$

Finally, we take the natural logarithm of the Odds,

$$
\ln (\text { Odds })=\ln \left(\frac{\hat{\pi}_{i}}{1-\hat{\pi}_{i}}\right)=\beta_{0}+\beta_{i} X_{i} .
$$

Equation (4) is the logit transform and is linearly related to the parameters, $\beta_{i}$, of Eqn (1). A detailed and rigorous discussion of the logistic regression model can be found in Hosmer and Lemeshow (2013). 


\section{Data sources}

We are interested in understanding if the breakup of the $\mathrm{N} \varnothing I \mathrm{~B}$ is related to a particular set of climate conditions. For example, is the breakup a response to thermal weakening due to melt season conditions? If so, then surface air temperature (SAT) might be a factor. We found that the average June air temperature at the Danish Meteorological Institute (DMI) stations of Danmarkshavn, the HKH islands and Station Nord $\left(81.6^{\circ} \mathrm{N}, 16.65^{\circ} \mathrm{W}\right)$ increased by $\sim 1^{\circ} \mathrm{C}$ between 1986 and 2013 at all three station. These SAT increases are consistent with those found by Bekryaev and others (2010) throughout the Arctic.

Steele and others (2008) report that the Arctic Ocean has experienced a pronounced warming since 1995 for example, with a $5^{\circ} \mathrm{C}$ temperature anomaly during the summer of 2007 . Has the sea surface temperature (SST) in the vicinity of the NØIB experienced a similar warming that might contribute to the weakening of ice barrier by reducing the first-year ice thickness or increasing subsurface melting?

Clouds cool the surface by reflecting shortwave radiation back into space and warm the surface by absorbing outgoing longwave, infrared radiation (Serreze and Barry, 2005; Zygmuntowska and others, 2011). In the Arctic, clouds tend to warm the surface throughout most of the year with a brief period of cooling at mid-summer (Intrieri and others, 2002). Does the variabilty of cloud cover over the NØIB contribute to SAT increases and increased surface melting?

Is it a mechanically-forced disintegration due to wind patterns? We found that the average wind direction at Danmarkshavn during January, February, and March is $260^{\circ}$ from the north while the June, July and August directions are $187^{\circ}, 194^{\circ}$ and $202^{\circ}$, respectively. The summer winds would tend to drive ice floes away from the coast.

Or does some combination of thermal and mechanical conditions drive the breakups? To address these questions, the following climate and weather (Table 1) datasets are used as input IVs to the logistical model.

The monthly average SAT measured at $2 \mathrm{~m}$ above ground, wind speed and direction, and the monthly positive degree days (PDDs) were calculated from daily values at the DMI stations at Danmarkshavn and the $\mathrm{HKH}$ islands (Fig. 1; Cappelen, 2014). At the time of this writing (November 2015), the DMI data for HKH and Danmarkshavn for 2014 have not been analyzed nor have monthly averages been computed, therefore the breakup of the ice barrier in 2014 is not included in this analysis. The SST are taken from the NOAA OI SST V2 dataset available at the NOAA web site http://esrl.noaa.gov/psd/ for the area bounded by $80^{\circ}$ North, $020^{\circ}$ West and $76^{\circ}$ North, $010^{\circ}$ West. The wind direction data from HKH for June, July and August are very suspicious. For 11 of the 28 years of this analysis the wind direction did not change for weeks and months at a time. While the model can work with some missing data, too much of the wind data is missing or erroneous for it to be of use. The wind speed data from $\mathrm{HKH}$ appears to be correct. The cloud cover data are for the area bounded by $80^{\circ}$ North, $020^{\circ}$ West and $76^{\circ}$ North, $010^{\circ}$ West come from Riddaway, 2006.

\section{Model results}

The models were created using the $R$ statisitical computing package (R Core Team, 2014). We start by using the backwards, stepwise strategy (the $R$ glmulti package (Calcagno
Table 1. Logistic model IV data

\begin{tabular}{lll}
\hline Data & Location & Period \\
\hline SST & See data sources & Monthly average, JJA \\
SAT & HKH & Monthly average, JJA \\
SAT & Danmarkshavn & Monthly average, JJA \\
PDDs & HKH & Monthly average, JJA \\
PDDs & Danmarkshavn & Monthly average, JJA \\
Wind speed & HKH see data sources & Monthly average, JJA \\
Wind speed & Danmarkshavn & Monthly average, JJA \\
Wind direction & Danmarkshavn & Monthly average, JJA \\
Cloud cover & See data sources & Monthly average, JJA \\
\end{tabular}

and de Mazancourt, 2010)) to construct a model by including 27 IVs (Table 1) and then, one by one, removing a variable while observing various goodness-of-fit criteria. As a general rule the fewer IVs, i.e. the more parsimonious a model the better because such a model is more likely to work well with other datasets (Hosmer and Lemeshow, 2013). A more specific criterion is the Akaike Information Criterion (AIC), which is a measure of the goodness-of-fit based on the residual deviance - the smaller the AIC value, the better the model (Symonds and Moussalli, 2011).

Next, models using various combinations of the IVs from the candidate model created with glmulti are analyzed. Another criterion is the Area Under Curve (AUC) of the Receiver Operating Characteristics test (Eng, 2005), where the larger the $A \cup C$, the better predictive accuracy the model; AUC values between 0.9 and 1.0 are deemed best, $0.8-0.9$ are good and no model with an AUC of $<0.50$ is considered. Additional $\chi^{2}$ tests, used in conjunction with the AIC and AUC, helped determine a good model. Finally, a linear dependence (collinearity) among several IVs is undesirable (Hosmer and Lemeshow, 2013). One test for collinearity is the variance inflation factor or VIF. While there are no hard-and-fast rules for acceptable VIF values $\left(\mathrm{O}^{\prime}\right.$ Brien, 2007) generally, the smaller the values for the IVs, the better. All of these criteria were used to evaluate the models. The model that best satisfied the various inter-dependent criteria is one using the number of June PDD at Danmarkshavn and the average July wind speed at Danmarkshavn as the IVs to account for the breakup of the NØIB. The AIC equals 15.66, the AOC is 0.97 and VIF values are 6.1 for the IVs.

We performed two what-if exercises to observe how the probability of a breakup might change with varying IV values; the results are shown in Figure 3. In each of the exercises the median value of one variable was used and the second variable was varied over range between known minima and maxima. For example, in Figure 3a, the median value for the July wind speed is $3.6 \mathrm{~ms}^{-1}$ and the number of June PDDs increments by 10 from 5 to 120 . When the number of June PDDs reaches 65 there is a $97 \%$ probablity of a breakup if wind speed equals its median value. In Figure $3 \mathrm{~b}$, the wind speed is varied from 0 to 7 $\mathrm{ms}^{-1}$ while the median June PDDs equals 50. Stated in terms of odds, for each 5 PDD increase, the odds of a breakup are 1.17 times that of there being no breakup.

The plot in Figure 3b seems counter-intuitive; one would expect that the probability of breakup might increase with increasing wind speed. What the plot demonstrates is the sensitivity of breakup to the number of June PDDs regardless of 

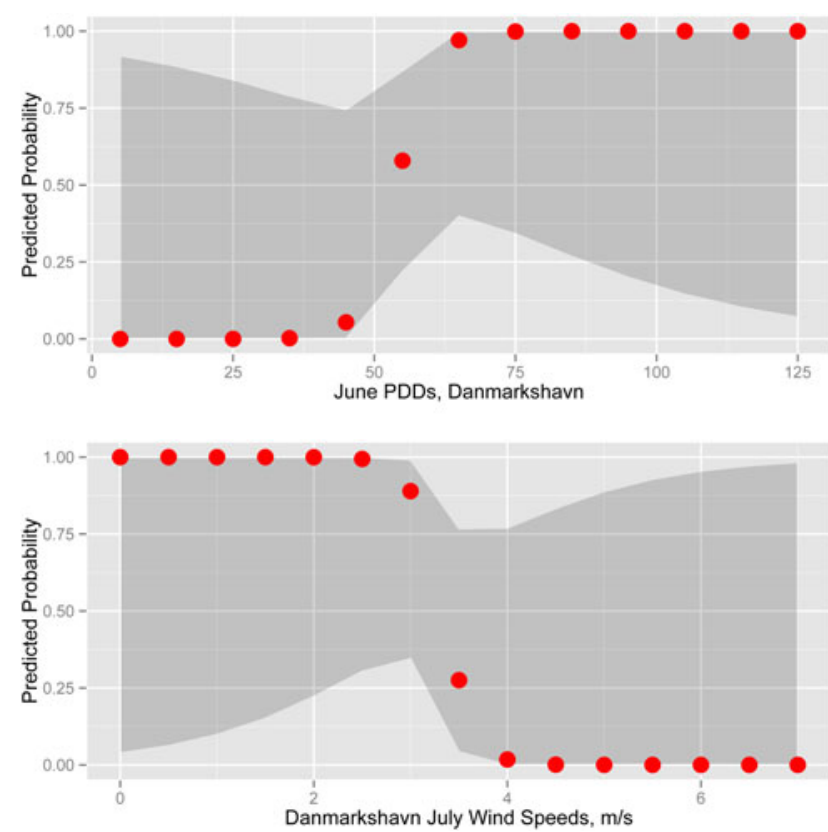

Fig. 3. The two IVs that produced the best statistical model. The gray bands are the $95 \%$ confidence interval. See the section Model results for a detailed discussion.
July's average wind speeds. If we increase the number of June PDDs to 90 , the probability of breakup remains $>90 \%$ until the speed reaches $5.5 \mathrm{~ms}^{-1}$. With a further increase of PDDs to 110 (not an unrealistic number; see Fig. 4), the probability of breakup is $45 \%$ at $6.5 \mathrm{~ms}^{-1}$. It should be noted that, for the period 1986-2013, the average July wind speed has only twice exceeded $5.0 \mathrm{~ms}^{-1}: 1991\left(5.5 \mathrm{~ms}^{-1}\right)$ and 1986 (6.2 $\left.\mathrm{ms}^{-1}\right)$.

If we use the 1986-2013 median values for June PDDs and July wind speed at Danmarkshavn (50 and $3.6 \mathrm{~ms}^{-1}$, repectively) the probability of breakup is $\sim 22 \%$. If, however, we use the 2001-2013 median values for each $(58,3.2$ $\mathrm{ms}^{-1}$ the probability of breakup increases to $\sim 96 \%$. This is a further indication of how sensitive the breakup is to small changes in June PDDs. All probablilities have a 95\% confidence interval.

\section{Model prediction}

In the preceding section we examined the logistical model's explanatory capability; here we examine its predictive ability. We created a dataset with all the IVs listed in Table 1 but removed the years 2009 and 2010. We then reran the model with this reduced dataset (model f2). Next, we created two datasets, one for only 2009 and one for

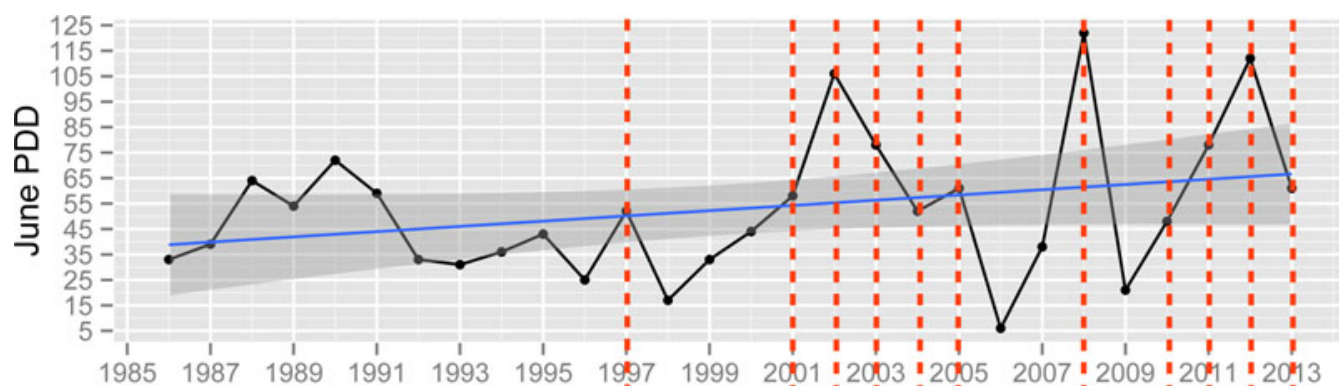

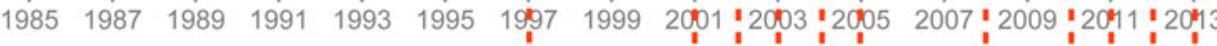
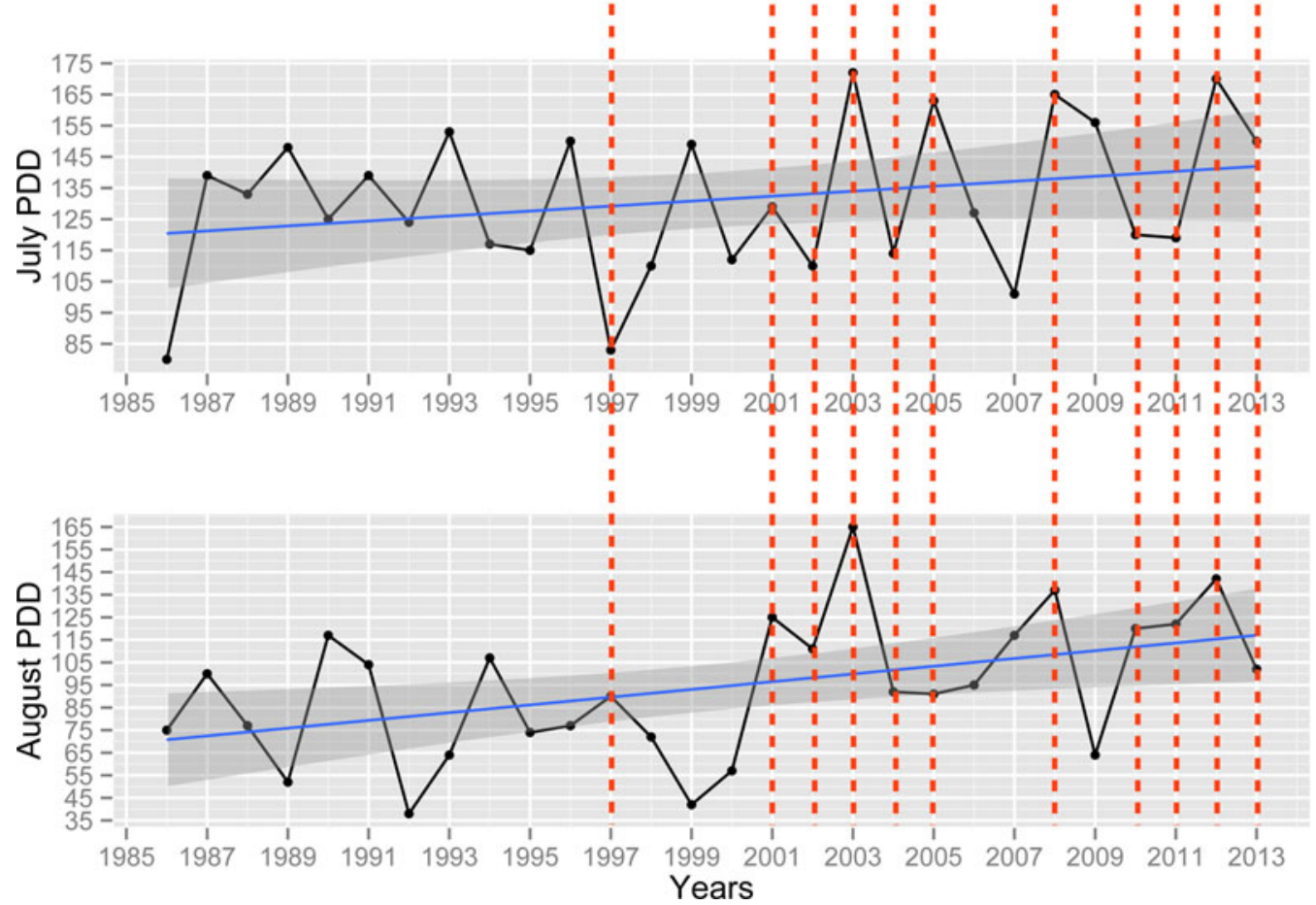

Fig. 4. June, July and August PDDs, 1986-2013, Danmarkshavn. The solid blue lines are the linear fit and the gray bands are the $95 \%$ confidence interval. The vertical red, dashed lines are the years when the NØIB broke up. Note that the vertical scale is different for each month. 


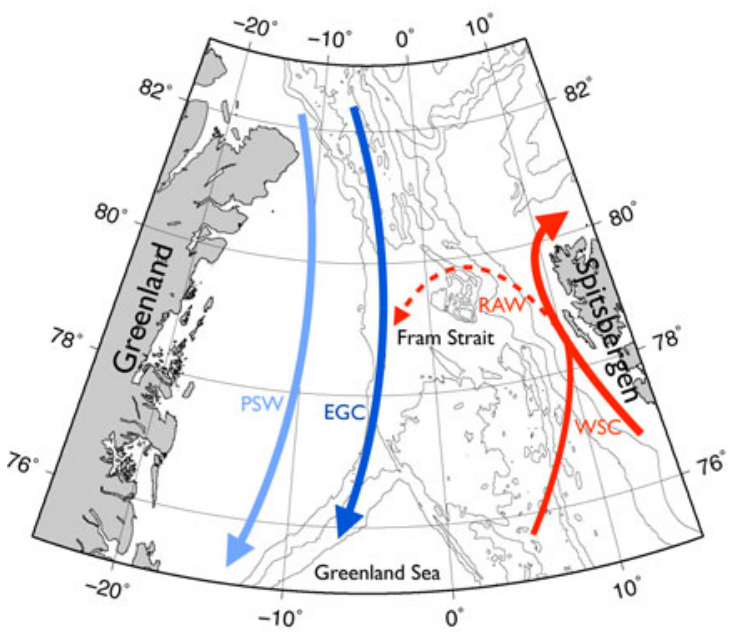

b

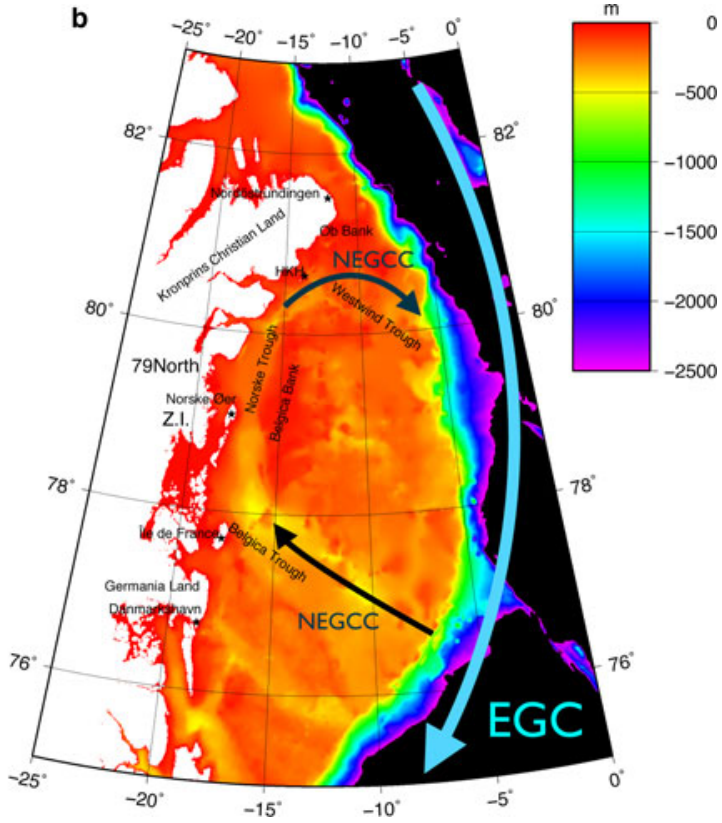

Fig. 5. (a) Currents in the Fram Strait and Greenland Sea. The depth contours are every $1000 \mathrm{~m}$. WSC is the West Spitsbergen Current of Atlantic Water, RAW is Return Atlantic Water, EGC is the East Greenland Current, and PSW is the Polar Surface Water current on the east Greenland shelf (after Rudels and others (2002)). (b) Bathymetric chart of the Northeast Greenland shelf. The figure is based on IBCAO Version 3, 30 arcsec data (Jakobsson and others, 2012) and was created using the GMT mapping software (Wessel and Smith, 1995). The general circulation patterns shown for the EGC (b) and the NEGCC are based on research by Paquette and others (1985), Bourke and others (1987), Budéus and Schneider (1995), and Budéus and others (1997).

only 2010 with all the IVs. We then ran a prediction algorithm using model $f 2$ with the 2009 and 2010 datasets. We repeated the process but this time deleted only 1997, created a new model, $\mathrm{f3}$, and ran prediction algorithm for the 1997 dataset.

For 2009 the algorithm predicted a $0.0024 \%$ probabilty of a breakup - the NØIB did not break up in 2009. For 2 a in which the NØIB was observed to break up, 1997 and 2010 , the algorithm predicted 36 and a $62 \%$ probabilty of a breakup, respectively.

\section{DISCUSSION}

Our analysis shows that the breakup of the NØIB is correlated with late-spring and early-summer regional weather conditions: warm conditions in the spring prime the ice barrier for mechanical deterioration during the summer and fall. All models are a simplification of a complex reality and the one presented here is no exception. By objective statistical measures, it is a good model because it satisfactorily describes how the state of the NØIB depends upon two climate-related variables. The model is also a reasonably accurate predictor of the state of the ice barrier. With one exception (2010) the model indicates that once the number of June PDDs at Danmarkhavn exceeds 50, breakup is likely to occur if the average July wind speed is $<4 \mathrm{~ms}^{-1}$. We see above (Fig. 3) that as the number of PDDs increases, the wind speed above which breakup does not occurr also increases. Why there is a wind speed threshold for a given number of PDDs above which breakup does not occur is unclear. If we assume that the amount of surface meltwater on the ice barrier increases with the number of PDDs, the action of wind on the surface water might aid in the breakup.

This conceptual model is consistent with Wadhams (1981) who proposes three basic mechanisms of fast ice breakup that follow a period of the weakening of the ice by surface melting and/or basal melting: breakup by propagating waves through the ice, breakup due to waves at the ice edge and breakup by wind stresses. If the fast ice is of a uniform thickness the propagating waves will not cause fracture within the ice. However, the NØIB is not uniformly thick and is criss-crossed with cracks, small pressure ridges and open water leads, all of which are areas of local stress caused by the propagating wave. Furthermore, the effects of the propagating waves are amplified as the waves move from deep water into shoal waters and the wave amplitude increases, which generates bending stresses on the ice. Wind stress on the fast ice pressure ridges tend to depress the ice in the downwind direction causing the ice to fracture. The sail height of grounded pressure ridges is also an important factor in breakup (Petrich and others, 2012) but there are no data on such ridges on the NØIB.

In the case of the NØIB, propagating waves through the ice and ice-edge waves may be more significant than wind stresses in the initial breakup of the ice barrier, while wind stresses and ocean currents are significant in the dispersion of the ice floes after breakup. Petrich and others (2012) also find that breakup can occur with little mechanical forcing if the ice has decayed due to surface melting, which lowers the ice albedo leading to more ablation and the formation of melt ponds. Such a mechanism is likely to be important in the breakup of the NØIB.

Several factors can contribute to the thermo-mechanical collapse, which we investigate below.

\section{Reduced ice thickness}

Ice thickness is an important engineering property and exerts an important control on how ice fails (Timco and Weeks, 2010). The principal factor controlling thickness of first- 
year sea ice is the length of the freezing season and the ambient air temperature, while other contributing factors include wind speed, ocean heat flux and surface radiation balance (Timco and Weeks, 2010). Field experiments on sea ice in the Canadian Arctic attributed a decreasing strength of thinning ice to a weakening of the ice lattice itself (with temperature) and an increase in porosity with a concomitant increase in brine volume within the ice (Johnston, 2006). Here we are interested in establishing if there is a detectable reduction in ice thickness of the NØIB. To do so, we derive ice thicknesses from SAT data for the period 1982-2012 and incorporate sporadic in situ and remotely-sensed estimates.

Sea ice thickness can be calculated using an empirical formula developed by V. Lebedev (Bilello, 1961; Yu and Lindsay, 2003). Serreze and Barry (2005, Chap. 7) note that the growth of sea ice up to $\sim 1 \mathrm{~m}$ can be approximated by freezing degree days (FDD). Lebedev's formula is

$$
h=1.33 F D D^{0.58},
$$

where $h$ is the thickness in $\mathrm{cm}$ and FDD is the cumulative sum of daily average temperature below which sea water freezes. The freezing point of $S=33.5$ sea water is $\sim-1.8^{\circ} \mathrm{C}$, typical of near-surface waters in the western Fram Strait (Straneo and others, 2012). The FDDs were calculated using temperature data from the weather station at Danmarkshavn. The 1982/83 winter had the greatest number of FDDs (4510) for the 30 a between 1982 and 2012 while 2005/06 had the fewest FDDs (3765) during the same three decades. Since 2001, the mean number of yearly FDDs has been 4000 . Based on Eqn (5), calculated ice thicknesses range from 1.6 to $1.8 \mathrm{~m}$ (Table 2).

There are only a few sporadic in situ measurements of the thickness on NØIB. Early measurements by de Gerlache (1906) in August 1905 showed ice south of île de France was $\sim 3 \mathrm{~m}$ thick. Schneider and Budéus (1995) report the ice was $2-3 \mathrm{~m}$ thick between $79 \mathrm{~N}$ and Norske Øer in the summer of 1993. More recently Wadhams and others (2006) report first-year ice was 1.1-1.9 m thick in August 2004.

We attempted, with limited success, to use ICESat L2 Sea Ice Altimetry Data (GLA13, V33) (Zwally and others, 2011) and Moderate Resolution Imaging Spectroradiometer (MODIS) images to determine the ice thickness at the edge of the ice barrier. The purpose of MODIS imagery is to unambiguously detect open water. The corrected sea surface height serves as the reference plane from which sea ice freeboard is measured for conversion to ice thickness. We used ICESat data from campaigns 2C (18 May-21 June 2004) and 3C (20 May-23 June 2005). A major difficulty was finding cloud-free MODIS images concurrent with an

Table 2. Estimates of ice thickness on NØIB derived from Lebedev's equation, Eqn (5)

\begin{tabular}{lll}
\hline Year & 1 October-31 May FDDs & $\begin{array}{l}\text { Ice thickness } \\
\mathrm{m}\end{array}$ \\
\hline $1982 / 83$ & 4510 & 1.8 \\
$2003 / 04$ & 4025 & 1.6 \\
$2005 / 06$ & 3765 & 1.6 \\
$2011 / 12$ & 4035 & 1.6 \\
\hline
\end{tabular}

ICESat track that passed over both open water and the ice edge. On the few occasions when all conditions were met, we estimated ice thicknesses of $\sim 1.2-1.5 \mathrm{~m}$ using the methods set out in Spreen and others (2006) and Kwok and others (2007).

Given the limited number of measurements between 1905 and 1993 and no known frequent breakups during the 88 year period, this suggests that the multi-year ice of the NØIB was $\sim 3 \mathrm{~m}$ thick. The thickness measurements by Wadhams and others (2006) and our ICESat estimates are of first-year fast ice and closely agree with those derived from Lebedev's equation. The NØIB now appears to be thinner than in previous decades (by $\sim 0.2 \mathrm{~m}$ or $\sim 11 \%$ ), which might be a factor in its nearly annual breakup since 2001 .

\section{Meltwater on the ice barrier}

The presence of surface meltwater can weaken sea ice and hasten its break up (Stroeve and others, 2014). It is a ubiquitous feature of the NØIB, having been observed by de Gerlache (1906), Gudmandsen and others (1995) and Schneider and Budéus (1997; Fig. 3).

The number of June, July and August PDDs has steadily increased since 1993 (Fig. 4) and we would expect the amount of meltwater on the ice barrier to have increased as well, which would decrease its albedo leading to even more melting. Regional climate models (Burgess and others, 2010; Franco and others, 2012) suggest that annual accumulation rate in Northeast Greenland has remained constant for the period 1958-2010 at between $200 \mathrm{~mm}$ w.e. $\mathrm{a}^{-1}$ (Franco and others, 2012) and $310 \mathrm{~mm}$ w.e. $\mathrm{a}^{-1}$ (Burgess and others, 2010). Thus, it is likely that any additional meltwater on the fast ice is not due to increased snowfall during the previous winter but to melting of the fast ice itself.

We attempted to quantify the surface area covered with meltwater - ponds, leads, surface streams and un-ponded water - for the years 2001-2014 with the MODIS data product MOD09GA, Daily Surface Reflectance, which has a spatial resolution $500 \mathrm{~m}$. However, as the first-year fast ice thins and becomes translucent, discriminating between ocean water below the ice and surface meltwater becomes very problematic with spectral data from MOD09GA imagery. In the end, we were unable to make interannual comparisons of the areal extent of meltwater during a fixed period (mid-July).

\section{Warming of the water beneath NØIB}

The NØIB can be thin due to melting from above as well as from below. In recent decades there have been two warm pulses of Atlantic Water (AW) entering the Arctic Ocean via the West Spitsbergen Current (WSC) (Fig. 5a) through the eastern Fram Strait - one in the early 1990s and a second from 2004 to 2007 (Beszczynska-Möller and others, 2012). Warming has also occurred in the Return Atlantic Water (RAW) and the East Greenland Current (EGC) albeit to a lesser degree; see, for example, (Polyakov and others, 2011, Fig. 2) and (Dye and others, 2012, Fig. 72). Two questions present themselves: (1) is there a mechanism or pathway that might bring this anomalously warm water under the NØIB and (2) is there any evidence that it is occurring?

In answer to the first question, the Belgica Trough (Fig. 5b) is an ideal pathway and topographic steering is the likely 
mechanism creating the Northeast Greenland Counter Current (NEGCC) bringing warmer Atlantic Intermediate Water (AIW) into the trough system beneath much of the NØIB. Sutherland and Pickart (2008) have proposed that topographic steering creates the East Greenland Coastal Current along the southeast coast of Greenland. The answer to the second question is more complex.

Bourke and others (1987) found warm waters $\left(>0^{\circ} \mathrm{C}\right)$ at both the southeast and northwest ends of the Belgica Trough at a depth of $\sim 200 \mathrm{~m}$, with the warmest water $\left(>1^{\circ} \mathrm{C}\right)$ near the southern end of the Norske Trough. Mayer and others (2000) report a water mass with temperatures in the range $-0.5^{\circ} \mathrm{C}\left(150 \mathrm{~m}\right.$ depth) to $1.0^{\circ} \mathrm{C}$ at a depth of $380 \mathrm{~m}$. Straneo and others (2012) obtained temperature data $30-40 \mathrm{~km}$ to the east of the $79 \mathrm{~N}$ terminus in the Norske Trough and found water with a potential temperature $>1{ }^{\circ} \mathrm{C}$. In all these cases, the warmer water is capped by cooler, less saline water. It is not clear how the warm and relatively deep water might give up its heat to contribute to the basal melting of the NØIB. Thus, what effect, if any, the warm (and possibly warming) water in the Belgica and Norske troughs has on the integrity of the ice barrier is an open question. In 2012, Dodd and others (2013) set an ice mass-balance buoy at the western edge of the NØIB, which may provide some answers.

While much different in extent and thickness than the NØIB, two of the ice shelves of Ellesmere Island, Nunavut, Canada (Ward Hunt and Ayles) have broken up and disappeared, and the Milne Ice Shelf is undergoing significant volume and area changes (Mortimer and others, 2012). The region has experienced increases in the mean annual temperature over the last 50-60 a and climate reanalysis indicates that once the number of PDDs exceeds 200, ice shelf calving occurs (Mueller and others, 2003; Copland and others, 2007). Ice shelf mass balance includes gains and losses to surface and underside of the ice, and one possible contributor to the breakup of Ward Hunt may have been changes to ocean temperature, salinity and currents (Mueller and others, 2003).

\section{CONCLUSIONS}

We have shown that the NØIB has broken up during the summers of 2001-2005, 2008, and 2010-2014. This new behavior contrasts with its perennial presence during the last few decades, in which only 1-2 breakups occurred. A logisitic regression model shows that the odds of breakup are strongly linked to the June PDDs and July winds as recorded at nearby weather stations. This leads us to conclude that thermo-mechanical forcing is an important control on the stability of the NØIB.

In the years since 2001 the fast ice matrix of ice barrier has been predominantly first-year fast ice. Maslanik and others (2011) report a continuing decrease in the extent of multiyear ice in the Arctic Ocean but Spreen and others (2009) found no clear trend in the ice thickness exiting the Arctic through the Fram Strait, which leads us to believe that the thickness of the floes frozen into the matrix has remained constant and does not affect the integrity of the ice barrier. There is no longer a persistent core (Schneider and Budéus, 1995) of multi-year fast ice in the ice barrier and, as the summers continue to warm in the region (Fig. 4), it is unlikely that the NØIB will again be a year-round, semi-permanent feature of the Northeast Greenland coast.

\section{ACKNOWLEDGEMENTS}

We thank the Scientific Editor, Hartmut Hellmer, and two anonymous reviewers for their comments and suggestions, which have materially improved this manuscript. G. S. H. is funded by NESSF and NASA award NNX13AK88C

\section{REFERENCES}

Amundson J and Truffer M (2010) A unifying framework for icebergcalving models. J Glaciol., 56(199), 822-830 (doi: 10.3189/ 002214310794457/73)

Bamber J and 10 others (2013) A new bed elevation dataset for Greenland. Cryosphere, 7, 499-510 (doi: 10.5194/tc-7-499-2013)

Bekryaev R, Polyakov I and Alexeev V (2010) Role of Polar amplification in the long-term surface air temperature variations and modern Arctic warming. J. Clim., 23, 3888-3906 (doi: 10. 1175/2010JCLI3297.1)

Bennike O, Mikkelsen N, Forsberg R and Hedenäs L (2006) Tuppiap Qeqertaa (Tobias Island): a newly discovered island off northeast Greenland. Polar Rec., 42(223), 309-314 (doi: 10.1017/ S003224740600550X)

Beszczynska-Möller A, Fahrbach E, Schauer U and Hansen E (2012) Variability in Atlantic water temperature and transport at the entrance to the Arctic Ocean, 1997-2010. ICES J. Marine Sci., 69, 1-12 (doi: 10.1093/icesjms/fss056)

Bilello MA (1961) Formation, growth, and decay of sea-ice in the Canadian Arctic Archipelago. Arctic, 14(1), 2-24 (doi: 10.14430/arctic3658)

Bourke RH, Newton JL, Paquette RG and Tunnicliffe MD (1987) Circulation and water masses of the East Greenland Shelf. J. Geophys. Res., 92(C7), 6729-6740 (doi: 10.1029/ JC092iC07p06729)

Budéus G and Schneider W (1995) On the hydrology of Northeast Water Polynya. J. Geophys. Res., 100(C3), 4287-4299 (doi: 10.1029/94JC02024)

Budéus G, Schneider W and Kattner G (1997) Distribution and exchange of water masses in the Northeast Water Polynya (Greenland Sea). J. Marine Syst., 10, 123-138 (doi: 10.1016/ S0924-7963(96)00074-7)

Burgess EW and 6 others (2010) A spatially calibrated model of annual accumulated rate on the Greenland Ice Sheet (19582007). J. Geophys. Res., 115, F02004 (doi: 10.1029/2009 JF001293)

Calcagno V and de Mazancourt C (2010) glmulti: an R package for easy automated model selection with (Generalized) linear models. J. Stat. Softw., 34(12), 1-29

Cappelen J (2014). Weather observations from Greenland 19582013. Tech. Rep. Danish Meteorological Institute

Copland L, Mueller DR and Weir L (2007) Rapid loss of the Ayles Ice Shelf, Ellesmere Island, Canada. Geophys. Res. Lett., 34, L21501 (doi: 10.1029/2007GL031809)

de Gerlache A (1906) The North-East Coast of Greenland, beyond 77 Degrees N. Lat. Bull. Am. Geogr. Soc., 38(12), 721-729 (doi: 10.2307/197648)

Dodd PA, Granskog M, Spreen G, Gerland S and Hansen E (2013) The supply of warm Atlantic Water to the Nioghalvfjerdsbræn in north east Greenland. In International Workshop on Ice Sheet/Ocean/Atmospheric Interactions in Greenland, 4-7 June 2013. Beverley, MA, USA

Dye S, Nolan G and Beszcznska-Möller A (2012) ICES Report on Ocean Climate 2011. Tech. Rep. International Council for the Exploration of the Sea

Eng J (2005) Receiver operating characteristic analysis: a primer Acad. Radiol., 12(7), 906-916 (doi: 10.1016/j.acra.2005.04.005)

Franco B, Fettweis X, Lang C and Erpicum M (2012) Impact of spatial resolution on the modelling of the Greenland ice sheet surface mass balance between 1990-2010, using the regional climate model MAR. Cryosphere, 6, 695-711 (doi: 10.5194/tc-6-6952012) 
Gudmandsen P, Thomsen BB, Pedersen LT, Skriver H and Minnett PJ (1995) North-East Water polynya: satellite observations summer 1992 and 1993. Int. J. Remote Sens., 16(17), 3307-3324 (doi: 10.1080/01431169508954632)

Hosmer DW and Lemeshow S (2013) Applied Logistic Regression, 3rd edn. Wiley, Hoboken, NJ

Intrieri JM and 6 others (2002) An annual cycle of Arctic surface cloud forcing at SHEBA. J. Geophys. Res., 107(C10) (doi: 10.1029/2000JC000439)

Jakobsson $M$ and 30 others (2012) The international bathymetric chart of the Arctic Ocean (IBCAO) version 3.0. Geophys. Res. Lett., 39(12) (doi: 10.1029/2012GL052219)

Johnston M (2006) A comparison of the physical properties and strength of decaying first-year ice in the Arctic and sub-Arctic. Ann. Glaciol., 44, 154-162 (doi: 10.3189/17275640 6781811664)

Koch L (1935) A day in North Greenland. Geogr. Ann., 17, 609-620 (doi: 10.2307/519888)

Kwok R, Cunningham GF, Zwally HJ and Yi D (2007) Ice, cloud, and land elevation satellite (ICESat) over the Arctic sea ice: retrieval of freeboard. J. Geophys. Res., 112, C12013 (doi: 10.1029/ 2006JC003978)

Maslanik J, Stroeve J, Fowler C and Emery W (2011) Distribution and trends in Arctic sea ice age through spring 2011. Geophys. Res. Lett., 38(L13502) (doi: 10.1029/2011GL047735)

Mayer C, Reeh N, Jung-Rothenhäusler F, Huybrechts P and Oerter H (2000) The subglacial cavity and implied dynamics under Nioghalvfjerdsfjorden Glacier, NE-Greenland. Geophys. Res. Lett., 27(15), 2289-2292 (doi: 10.1029/2000GL011514)

Mortimer CA, Copland L and Meuller DR (2012) Volume and area changes of the Milne Ice Shelf, Ellesmere Island, Nunavut, Canada, since 1950. J. Geophys. Res., 117(F4) (doi: 10.1029/ 2011/JF002074)

Mueller DR, Vincent WF and Jefferies MO (2003) Break-up of the largest Arctic ice shelf and associated loss of an epishelf lake. Geophys. Res. Lett., 30(20), 2031-2034 (doi: 10.1029/ 2003GL01931)

O'Brien RM (2007) A caution regarding rules of thumb for variance inflation factors. Qual. Quant., 41, 673-690 (doi: 10.1007/ s11135-006-9018-6)

Paquette RG, Bourke RH, Newton JF and Perdue WF (1985) The East Greenland Polar Front in autumn. J. Geophys. Res., 90(C3), 4866-4882 (doi: 10.1029/JC090iC03p04866)

Petrich C and 5 others (2012) Coastal landfast sea ice decay and breakup in northern Alaska: key processes and seasonal prediction. J. Geophys. Res., 117, C02003 (doi: 10.1029/2011JC007339)

Polyakov I and 20 others (2011) Fate of early 2000s Arctic warm water Pulse. Bull. Am. Meteorol. Soc., 561-566 (doi: 10.1175/ 2010BAMS2921.1)

R Core Team (2014) $R$ : a language and environment for statistical computing. R Foundation for Statistical Computing, Vienna, Austria

Reeh N, Thomsen HH, Higgins AK and Weidick A (2001) Sea ice and the stability of north and northeast Greenland floating glaciers. Ann. Glaciol., 33, 474-480 (doi: 10.3189/17275 640178181554)

Riddaway R (2006) ECMWF Newletter. Tech. Rep. 110. European Centre for Medium-Range Weather Forecasts

Rudels B, Fahrback E, Meinke J, Budéus G and Eriksson P (2002) The East Greenland Current and its contribution to the Denmark Strait overflow. ICES J. Marine SCi., 59, 1133-1154 (doi: 10.1006/ jmsc.2002.1284)

Schneider W and Budéus G (1994) The North East Water polynya (Greenland Sea): a physical concept of its generation. Polar Biol., 14, 1-9 (doi: 10.1007/BF00240265)
Schneider W and Budéus G (1995) On the generation of the Northeast Water Polynya. J. Geophys. Res., 100(C3), 42694286 (doi: 10.1029/94JC02349)

Schneider W and Budéus G (1997) A note on Norske Ø ice barrier (Northeast Greenland), viewed by Landsat 5 TM. J. Marine Syst., 10, 99-106 (doi: 10.1016/S0924-7963(96)00076-0)

Serreze MC and Barry RG (2005) The Arctic Climate System. Cambridge University Press, New York

Spreen G, Kern S, Stammer D, Forberg R and Haarpainter K (2006) Satellite-based estimates of sea-ice volume flux through the Fram Strait. Ann. Glaciol., 44, 321-328 (doi: 10.3189/ 172756406781811385)

Spreen G, Kern S, Stammer D and Hansen E (2009) Fram Strait sea ice volume export estimated between 2003 and 2008 from satellite data. Geophys. Res. Lett., 36(L19502) (doi: 10.1029/ 2009GL039591)

Steele M, Ermold W and Zhang J (2008) Arctic Ocean surface warming trends over the past 100 years. Geophys. Res. Lett., 35, L01614 (doi: 10.1029/2007GL031651)

Straneo F and 8 others (2012) Characteristics of ocean waters reaching Greenland's glaciers. Ann. Glaciol., 53(60), 202-210 (doi: 10.3189/2012AoG60A059)

Straneo F and 15 others (2013) Challenges to understanding the dynamic response of Greenland's marine terminating glaciers to oceanic and atmospheric forcing. Bull. Am. Meteorol. Soc., 1131-1144 (doi: 10.1175/BAMS-D-12-00100.1)

Stroeve JC, Markus T, Boisvert L, Miller J and Barett A (2014) Changes in Arctic melt season and implications for sea ice loss. Geophys. Res. Lett., 41, 1216-1225 (doi: 10.1002/2013 GL058951)

Sutherland DA and Pickart RS (2008) The East Greenland coastal current: structure, variability and forcing. Prog. Oceanogr., 78, 58-77 (doi: 10.1016/j.pocean.2007.09.006)

Symonds MRE and Moussalli A (2011) A brief guide to model selection, multimodel inference and model averaging in behavioral ecology using Akaike's information criterion. Behav. Ecol. Sociobiol., 65(1), 13-21 (doi: 10.1007/s00265-010-1037-6)

Timco GW and Weeks WF (2010) A review of the engineering properties of sea ice. Cold Reg. Sci. Technol., 60, 107-129 (doi: 1016/ j.coldregions.2009.10.003)

Wadhams P (1981) The ice cover in the Greenland and Norwegian seas. Rev. Geophys. Space Phys., 19(3), 345-393 (doi: 10.1029/ RG019i003p00345)

Wadhams P, Wilkinson JP and McPhail SD (2006) A new view of the underside of Arctic sea ice. Geophys. Res. Lett., 33, L04501 (doi: 10.1029/2005GL025131)

Wessel P and Smith WHF (1995) New version of the Generic Mapping Tools released, EOS Trans. Am. Geophys. Union, 76 (33), 329

World Meteorological Organization (2014) Sea Ice Nomenclature, March, 2014. Tech. Rep. World Meteorological Organization. http://www.jcomm.info.

Yu Y and Lindsay RW (2003) Comparison of thin ice thickness distributions derived from RADARSAT Geophysical Processor System and advanced very high resolution radiometer data sets. J. Geophys. Res., 108, 3387-3398 (doi: 10.1029/2002 JC001319)

Zwally H and 7 others (2011) GLAS/ICESat L2 Sea Ice Altimetry Data. Version 33. Campaigns 2C and 3C. In National Snow and Ice Data Center, Boulder, Colorado, USA, digital media

Zygmuntowska M, Mauritsen T, Quaas J and Kaleschke L (2011) Arctic clouds and surface radiation - a critical comparison of satellite retrievals and the ERA-interim reanalysis. Atmos. Chem. Phys. Discuss., 11, 31495-31522 (doi: 10.5194/acp-126667-2012) 